\title{
Expanded Universes in Science Fiction: A Matter of Integration
}

\author{
Universos expandidos: uma questão de \\ integração
}

\author{
Arthur Maia Baby Gomes ${ }^{1}$ \\ Elaine Barros Indrusiak ${ }^{2}$
}

DOI: 10.19177/memorare.v8e1202147-60

\begin{abstract}
Still lacking theoretical definitions, expanded universes are an artistic phenomenon often seen in science fiction literature as well as in narratives in other media. This text proposes a mechanism to explain how these universes come into being. For this, we analyze a series of cases such as Robert A. Heinlen's Future History, Ursula K. Le Guin's Hainish Cycle, George R. R. Martin's Thousand Worlds, Joanna Russ' Whileaway, and transmedia examples such as the Marvel Cinematic Universe. Borrowing from Tamar Yacobi's concept of mechanisms of integration - ways in which the reader makes sense of inconsistencies or oddities in a narrative - we argue that the explanation that two or more independent stories are set in a common universe is a hypothesis generated by the reader to integrate coincidences between these stories.
\end{abstract}

Keywords: Expanded Universes. Mechanisms of Integration. Science Fiction.

Resumo: Ainda sem definições teóricas bem delineadas, universos expandidos constituem um fenômeno artístico comum em narrativas de ficção científica, sejam literárias ou em outras mídias. Esse texto propõe um mecanismo para explicar como tais universos se formam, partindo de uma série de exemplos como a História Futura de Robert A. Heinlein, o ciclo Hainish de Ursula K. Le Guin, os Mil Mundos de George R. R. Martin e Whileaway de Joanna Russ, assim como de casos transmidiáticos, como o Universo Cinematográfico Marvel. Nos valemos do conceito de Tamar Yacobi de "mecanismos de integração", ou seja, as formas que leitores encontram para resolver inconsistências ou estranhezas em narrativas, para argumentar que a explicação de que duas ou mais histórias independentes se passam em um universo ficcional comum constitui uma hipótese do leitor para integrar coincidências encontradas nesses diferentes textos.

Palavras-chave: Ficção Científica. Mecanismos de Integração. Universos Expandidos.

\footnotetext{
1 Doutorando pela UFRGS na linha de pesquisa Sociedade, (Inter)textos Literários e Tradução nas Literaturas Estrangeiras Modernas. Estuda a obra de George R. R. Martin, com ênfase em sua inserção na literatura de ficção científica, através de abordagens vinculadas à narratologia funcionalista. arthurmaia1984@gmail.com 2 Doutora em Letras pela UFRGS, onde atua como professora do Departamento de Línguas Modernas e do Programa de PósGraduação. Realizou estágio pós-doutoral na Universidade de Miami. Desenvolve e orienta pesquisas nas áreas de literaturas estrangeiras modernas, estudos de narrativa, de intermidialidade e de tradução. Coordena o projeto Narratologia e Intermidialidade: novas mídias, novas abordagens e participa do Grupo de Pesquisa Intermídia: Estudos sobre a intermidialidade (UFMG/CNPq). elaine.indrusiak@ufrgs.br
}

Memorare, Tubarão, v. 8, n. 1, jan./jun. 2021. ISSN: 2358-0593 
Inventing a universe is tough work. Jehovah took a sabbatical. Vishnu takes naps. Science-fiction universes are only tiny bits of word-worlds, but even so, they take some thinking; and rather than think out a new universe for every story, a writer may keep coming back and using the same universe, sometimes till it gets a bit worn at the seams, softens up, feels natural, like an old shirt. (LE GUIN, 2010, p. 66-69).

Science fiction readers have been used to the concept of expanded universes for some time now. Nonetheless, this topic lacks theoretical approaches that aim to define it and explain its nature. Many studies on franchises and transmedia storytelling address similar phenomena and their findings might apply to expanded universes in general, although, no specific definition for this have come to our knowledge thus far. As a crucial differentiation of franchises and expanded universe, we propose that the later is made up by fictional pieces that share a temporal continuity which may or may not be presented in chronological order, yet, have independent narrative arcs. It is an instance of what Richard Saint-Gelais (2011) called "expansion transfiction", the usage of certain fictional elements across different texts alongside new material that is added to the original fictional universe. Traditional examples of that are sequential series, trilogies, sagas and such, which usually have this serial nature indicated on the cover, such as in Tiamat's Wrath (COREY, 2019), identified as "The Expanse 8". But there are looser forms of connecting different publications, such as the often used, though not consistently enough, reference to cycles ${ }^{3}$.

One of the earliest and most celebrated examples of expanded universes in science fiction is Robert A. Heinlein's Future History. In May 1941, editor John W. Campbell published in Astounding Magazine (CAMPBELL, 1941) a list of the stories that comprised this universe at that point. The fact that a list was needed reveals the major trait of Heinlein's Future History: the stories were not sequential in a noticeable way, but shared elements that hinted at connections, so that the reader could read each of them separately, but could also access them as parts of a larger universe, a choice that could significantly change interpretations.

Heinlein's model inspired other writers: Ursula K. Le Guin's Hainish tells of a future in which humanity developed mostly in peace and created an interplanetary league to exchange cultural and scientific knowledge. This universe comprises most of the author's greatest hits: The Left Hand of Darkness (2018), The Dispossessed (2011), and The Word for World is Forest (2015), as well as the triad of stories that took place in the planet 0 . None of said texts explicitly shares characters. Their stories take place centuries apart from each other. But the dating system, the common reference to the Hainish and the Ekumen league, and the ansible machine allow the reader to organize the different stories in a chronology, albeit tentatively. Ian Watson (1975) was the first scholar to create a chronological sequence for the Hainish Cycle. Le Guin (2010), on the other hand, recognized that continuity was not a

\footnotetext{
3 The term "short story cycle" or "short story sequence" has been studied and theorized about, but its definitions are frequently contradictory. According to Kennedy (1995), a cycle consists in a group of short stories that gravitate around a common theme, universe, or that complement each other, creating a larger narrative. The latter is what we aim to analyze in what follows, although, not necessarily restricted to short stories.
} 
major concern for her, and that "honest and earnest people" have tried to organize it, although she deems it an impossible task.

Unlike Le Guin, Isaac Asimov made a deliberate attempt to organize his own chronology in retrospect. Two of his independent series, Foundation and the Robot Stories, were unified decades after their original publication. Published twenty-nine years after its predecessor, the fourth novel in the first series, Foundation's Edge (2012a) incorporates references to the Robot novel, Caves of Steel (ASIMOV, 2011). In the author's note to Prelude to Foundation (2012b), Asimov explains his choice of integrating both universes, an suggests a reading order that includes both the Robot series and the Foundation ones. The contrast between Asimov's and Le Guin's vision on their expanded universes reveals the diversity of this literary phenomenon, and the fact that authorial intent might not be a defining factor.

The issue that remains unaddressed, however, is how readers can draw such links when the individual texts display no explicit and/or official connections, when there is no warning to the reader that a certain book is a sequence to others and that it should be read as part of a whole, as noted in the case of The Expanse series. Being that so, it is possible that, when one reads about the ansible in "Another Story, or A Fisherman of the Inland Sea" (LE GUIN, 2016), in that narrative universe ${ }^{4}$, one interprets it only considering what is presented in that story, or, if one knows Le Guin's fictional universe as a whole, connecting it to the technology first presented in The Dispossessed. So what are the theoretical grounds that help us understand the concept of a fictional universe shared by more than one work? Would readers unaware of the connection who read one story set in the Hainish Universe have their reading of the story fundamentally changed? If so, Literary studies - or even narrative theory - should be able to account for such disparate readings.

In George R. R. Martin's Thousand Worlds, a universe similar to Heinlein's and Le Guin's, knowledge of stories seemingly unrelated might change one's interpretation significantly. In Tuf Voyaging (2014), Haviland Tuf is an ecoengineer who recovers an ancient spaceship previously owned by the E.E.C., a military section from Earth that used biological weapons against their enemies. The E.E.C. symbol is the Greek letter theta, something that is mentioned eight times in /along the seven stories in which Tuf appears. References to the theta also appear in the novella "In the House of the Worm" (2005), this time in a more subtle way.

This story takes place on a devastated planet where people live inside caves and endure a war against creatures living in their underground levels, the grouns. The plot centers around Annelyn, a boy who goes deep into the caves to hunt a man who humiliated him. During his quest, he discovers that the grouns are the native population of the planet and have been dislodged by his own kind. From this point on, he tries to reconcile the warring groups. The novella offers no explicit reference to any other Thousand Worlds piece, except for the theta

\footnotetext{
${ }^{4}$ Borrowing the concept from Marie-Laure Ryan, who considers it as "the sum of the laws, states, and events, which make up
} the actual world of a narrative universe the factual domain" (1985, p. 720). 
symbol Annelyn finds in the labs where he discovers that grouns were experimented on. Without this information, the fact that the grouns were tortured and genetically modified by humans as a part of a biological war could not be inferred. Understanding/ Realizing this adds layers to the story, which now boarders on scientific experimentation, a topic frequently explored in science fiction literature since at least Mary Shelley's Frankenstein (2011) and which has become even more socially relevant since the revelation of the horrors perpetrated by Nazi scientists such as Dr. Mengele.

Tuf Voyaging, thus, answers some of the questions raised in "In the House of the Worm", just as Le Guin's The Dispossessed does in part for other Hainish stories. But only if the reader approaches the individual texts as part of a common timeline and a broader narrative universe. The role these connections play is to fill in gaps, to provide the reader with possible answers to the questions that emerge during the reading and that would remain unsolved by the end of the text. Meir Sternberg (1978) considers narrative gaps as a resource to create interest and drive narratives forward. Opening and closing expositional gaps generates specific effects that play on the reader's reactions. Some gaps may never be closed, whereas some may be filled by the reader's preexisting knowledge of elements of the fabula, such as characters, settings or events that are not limited to the story in hand. According to the author:

Even a number of modern writers may seem to share the expositional privileges or exemptions of their ancient predecessors. I am referring especially to novelists celebrated for their progressive creation of some private, full-fledged fictive world- Trollope's Barchester, Balzac's nineteenth-century France, or Faulkner's Yoknapatawpha County repeatedly carrying over not only settings but whole casts of characters and clusters of incidents from one work to another of the same cycle. But the same may be true of any series of works, notably detective stories, in which at least one central character recurs (e.g., Agatha Christie's Hercule Poirot), even though the setting of the fictive world varies.

Many critics work on the implicit (and sometimes even explicit) assumption that in all these cases at least part of the expositional antecedents may indeed be taken as known or obtained by the reader outside the limits of the single work, particularly with reference to different stories of the same cycle, which they regard as a single unit (STERNBERG, 1978, p. 2)

Sternberg goes on to explain that this assumption should not be taken for granted in literature pieces. Exemplifying with Shakespeare's Julius Caesar, in which historical data are freely adapted to meet the playwright's artistic needs, he notes that the reader's previous knowledge gathered from other works might be disregarded or even contradicted by the author, whose text is not subordinated to previous ones. Still according to the scholar, writers usually try to provide enough exposition, even when a particular work does not contradict any other material with which it might share characters, places, or events. Sound as it may be, Sternberg's analysis does not seem to take into consideration the science fiction field and its more than three decades of publishing expanded and coherent fictional universes. In a genre that has its fanbase as a key factor in its consolidation, coherence among

Memorare, Tubarão, v. 8, n. 1, jan./jun. 2021. ISSN: 2358-0593 
works of the same universe is regarded as a fundamental feature (REID, 2009). Farah Mendlesohn goes even further to point out that in the particular case of science fiction literature, the intersection between fans and writers is particularly large (MENDLESOHN, 2003).

In this sense, there is a way of reading science fiction texts that takes into consideration the long tradition of expanded universes. It creates its own premises, conventions, and generates its own effects in the readers who are acquainted with it. Think of a reader who reads Analog monthly, waiting for Martin's next story so he can catch references to the author's previous works and add another piece to the Thousand Worlds tapestry. This reader would be encouraged by authors and editors to do so (as in the situation when Campbell published a guide to Heinlein's Future History), and his reading of some pieces could be significantly changed accordingly, as demonstrated in the case of "In the House of the Worm". This reader represents the majority of science fiction fans from the 1930s to the 1980s, at least. In more recent years, the debates over whether a certain piece should be regarded as "canonic" 5 or not in a franchise, not only literary but often intermedia, surpassed the borders of the science fiction literature fandom. The transmedia franchise Star Wars, which opened with George Lucas's 1977 feature film and spread through novels, comics, TV series, and other media, established one of the most popular continuous fictional universes of all time, until 2014, when most of the existing material was retconned so they would cease to be canonic. So what happens to the particular readings and interpretations produced for years regarding these works' relation with the inaugural movies?

Such a relevant phenomenon should not remain unexamined, we believe $^{6}$. The general problem persists: where does the existence of this kind of universe lie, since the texts avoid explicit serialization and a monocratic decision from a corporation can dissolve decades of worldbuilding? However, fans still obsess over the notion of continuity, and intertextuality, and base their readings of particular events in the narrative on other literary pieces that only share a couple of features with the canonic work. Sternberg may have part of the answer, while another part comes from Tamar Yacobi's constructivist approach to (un)reliability.

In her seminal text, "Fictional Reliability as a Communicative Problem" (1981), the author aims at solving some problems found in Wayne Booth's classical proposition (BOOTH, 1983). Booth attributed the trait of (un)reliability to the narrator; when a narrator's morals and world views clash with those of the implied author, it is deemed unreliable. The implied author, however, remains as intangible as the nature of an expanded universe has seemed to us so far. Since we can only access the literary text through the narrative voice - the narrator's own or its mediation of the characters' - how are we to determine the implied author's morals? Besides, attributing psychological traits such as (un)reliability to narrators results in a troublesome personification of the narrative voice which does not apply to all literary narratives and

\footnotetext{
5 The term "canon" is used with its recurrent meaning of the set of material seen as officially part of a fictional universe. ${ }^{6}$ Star Wars fandom has been extensively examined (LYDEN, 2012), as well as its intermedia features, yet no work that discusses the nature of its shared continuity has come to our knowledge thus far.
} 
seems at odds with the categorization of other narrative elements as functions of the text, such as focalizers and the implied author itself. Aware of these shortcomings, Yacobi dislocates the assessment of reliability from the narrator to the narrative. This important constructivist switch considers the literary text as a communication act, thus restoring a more consistent role to the author as sender of the message.

The reader, in his turn, interprets the message as the receiver, posing hypotheses to explain any inconsistencies found in the text. In a more recent, expanded study of narrative (un)reliability, Sternberg and Yacobi propose that these hypotheses fall into six "mechanisms of integration", that is, six different ways in which the reader explains textual inconsistencies in order to achieve a satisfactory interpretation of the narrative. The mechanisms are:

a) The genetic: which points to the genesis of the text, the physical conditions of its writing, translation, editing, etc.

b) The generic: which relates the inconsistency to the tradition of the genre the text is said to belong to. In some genres, certain oddities are not only allowed, but encouraged, or even deemed essential.

c) The existential: which refers to the established rules of that particular universe.

d) The perspectival: which is associated to the limitations of information imposed by the narrator and the points of view through which the story is told.

e) The functional: through which the reader ascribes a functional role to the inconsistency as part of the aesthetic and thematic goals attributed to that particular narrative.

f) the figurative: through which one explains inconsistencies by considering them as figures of speech.

It is important to notice, as the authors do, that these mechanisms are not activated one at a time. Quite the contrary, they are frequently combined and it is very uncommon to propose an interpretation of textual idiosyncrasies without resorting to the functional mechanism, since most elements of a narrative - paradoxical and incoherent as they may appear to be - are usually perceived by readers as purposeful aesthetic or rhetoric devices. What matters most to our purposes here is the notion of (un)reliability as a hypothesis applied through the perspectival mechanism, sheer speculation, on the part of the reader, as to the coherence of the report in hand or, when applicable, to the trustworthiness of the reporter. Entertaining such questions regarding the truthfulness and accuracy of the narrative as whole, and not just of the narrative voice, potentially changes significantly the reading and the interpretations. Therefore, (un)reliability ceases to be perceived as a trait intrinsic to the literary text to become one possible interpretation raised in the act of reading. Likewise, establishing that an individual narrative relates to others as part of an expanded universe demands the application of integration mechanisms. Therefore, the very acknowledgement of an expanded universe as such is basically a reader's hypothesis, particularly when there are no authorial or editorial indications to confirm the broader nature of the work.

Memorare, Tubarão, v. 8, n. 1, jan./jun. 2021. ISSN: 2358-0593 
It is by resorting to the expanded universe hypothesis that readers put together scattered references and seemingly unrelated events so as to integrate the larger narrative context of which the fictional works are part. Although what is explained through this hypothesis may not necessarily constitute inconsistencies, the model works if we think of them as oddities (a word Yacobi often uses alongside "inconsistency") instead. Unlike inconsistencies, oddities such as references to common elements among independent texts - a staple of contemporary science fiction - do not necessarily curb the enjoyment or the interpretation of the fictional works on their own, but they raise questions as to the coherence of the narrative, to the author's creativity and originality as well as to possible intertextual relations not fully grasped. To make sense of this the reader must resort to at least four mechanisms of integration: generic, genetic, existential, and functional. Generic because this particular genre, recurrent in science fiction magazines and anthologies, has the expanded universes as one of its conventions. Genetic because it assumes the connections between the text and preexisting material to be part of the author's larger, serialized work. Existential because the fictional universe can only be fully grasped through the incorporation of elements from other works. And functional because inserting a fictional narrative within an expanded universe inevitably alters any previous interpretation or appraisal of the work.

As with most long narratives, the more a fictional universe expands, the more prone it becomes to displaying real inconsistencies. One particularly popular case of an expanded universe that has conflicting chronologies is the Marvel Cinematic Universe, known as MCU. The cinematographic adaptations of Marvel superheroes developed by Marvel Studios referenced each other from the very beginning. The famous sequence of movies that culminated in The Avengers (2012), included Iron Man appearing in Hulk's film, Hawkeye in Iron Man's, and so on. Later, the same universe was expanded to the TV format. In a partnership with ABC, Agents of S.H.I.E.L.D. (2013) was a television series centered around Phil Coulson, a character presented in The Avengers. Between 2015 and 2019, another partnership, this time with Netflix, brought to the streaming platform some more characters that verbally referenced the Avengers movies, but the connections were becoming looser, since no actor from the movies showed up on the Netflix series (and their participation in Agents of S.H.I.E.L.D. decreased over the years as well).

This distancing between the two media (movies and TV) is usually attributed to conflicts between two divisions in the Marvel Studios, a hypothesis that grew stronger as shows such as The Runaways (2017 and Cloak and Dagger (YEAR) were officially announced as part of the MCU, even though most viewers could barely recognize them as such. Things got even more complicated when the same characters started to appear in different versions in the movies and on TV, such as Tina Minoru, played by different actresses in Doctor Strange (2016) and in The Runaways. When the series running on Netflix met their endings, none later than 2020, Marvel Studios announced their own streaming shows, such as Wandavision (2021), leaving the previous works in an even cloudier zone. Eventually, things reached a point in which

Memorare, Tubarão, v. 8, n. 1, jan./jun. 2021. ISSN: 2358-0593 
establishing the MCU canon depends strongly on each viewer's conception of this universe and whether he or she deems logical that events that affected the entire universe (such as Thanos erasing half of living beings in Avengers: Infinite $\mathrm{War}^{7}$ ) were mentioned only briefly in some of the TV shows.

Further evidence of the hypothetical nature of shared universes can be found, again, in Martin's Thousand Worlds. In the novelette "And Seven Times Never Kill Man" (2006a), the trader Arik Ne'krol witnesses a slaughter on the planet of Corlos. A religious group called the Steel Angels, in a sort of holy war, attacks the native population, the Jaenshi, destroying their sacred pyramids and killing them indiscriminately. The god worshiped by the Steel Angels is called Bakkalon, the Pale Child. The story references the planet of Jameson's World, where the action of the short story "In This Tower of Ashes" (2006g) takes place. The Steel Angels are also briefly mentioned in "The Glass Flower" (2006d) and in Martin's first novel, Dying of the Light (2015). Such cross-references have supported the inclusion (by critics and fans alike) of all these works in the Thousand Worlds universe. Yet neither "The Lonely Songs of Laren Dorr" (2006f) nor Martin's hit series A Song of Ice and Fire seem to have made the cut, despite the fact that both of them bring references to Bakkalon, the Pale Child. Why is that?

The Lonely Songs of Laren Dorr is a short story first published in 1976, two years after "And Seven Times Nevel Kill Man", therefore, it would apparently fit the chronology perfectly. However, it is a fantasy story set in medieval scenarios (such as castles), and rather than a girl who lives on a distant planet, Sharra, the protagonist, is "a girl who goes between the worlds" (MARTIN, 2006f, p. 357). It involves magic as a central element, and neither Sharra nor her enemies are aliens or anything of the sort: they are gods with unlimited power. The story presents hyperboles typical of medievalist fantasy (GOMES; PEREIRA, 2020), and the recognition of this stylistic feature - an application of the generic mechanism - sets the story apart from science fiction.

Nonetheless, one of the seven gods who steal Sharra's lover, Kaydar, is familiar to Martin's frequent readers:

Laren stopped, and his eyes woke up again. "Ah, Sharra," he said. "Be careful how you go. Even your crown will not help you should they move on you directly. And the pale child Bakkalon will tear at you, and Naa-Slas feed upon your pain, and Saagael on your soul." (MARTIN, 2006, p. 364).

Strictly speaking, nothing in this short story contradicts any information in the Thousand Worlds canon, and it certainly shares an element with it. The situation is similar with $A$ Song of Ice and Fire, Martin's most famous work, widely known as an epic fantasy. In the fictional continent of Westeros, medieval-like noble families quarrel for power, while ice zombies and dragons rise from the North and the East. There are castles, magic rituals, gods allegedly bringing people back to life, and a large variety of religions. In the fourth novel, A Feast for Crows (2012), the character Arya Stark arrives at a temple of the Many-Faced

\footnotetext{
7 Only Agents of S.H.I.E.L.D. referenced the fact that half of the people in the universe had vanished for five years; oddly enough, this information was regarded as irrelevant to that TV series.
} 
God, where every other god can be worshiped. As the narrator describes the different altars, we are informed that

Thirty different gods stood along the walls, surrounded by their little lights. The Weeping Woman was the favorite of old women, Arya saw; rich men preferred the Lion of Night, poor men the Hooded Wayfarer. Soldiers lit candles to Bakkalon, the Pale Child, sailors to the Moon-Pale Maiden and the Merling King. (MARTIN, 2012, p. 447).

Again, Bakkalon seems to have followers in this fictional universe, as it has in the novelette where it first appears. These references have fed discussions among Martin readers on online forums (MKKAAYYY, 2017; POPPA, 2015; THELETHALCARROT, 2018) over the years, and the hypothesis most endorsed to explain away the oddity of finding sci-fi elements in works of fantasy is to read the mention to Bakkalon as just an homage the author paid to his own earlier work. This hypothesis found resonance in statements Martin wrote on his blog concerning his intentions (MARTIN, 2016). But it seems possible that readers in contact with the written texts would place Westeros in the Thousand Worlds, unaware of the author's opinions. We believe they usually do not (although they can), as in the case of Laren Dorr, because they explain this oddity - the reoccurrence of Bakkalon -, with genetic and generic arguments: it has to do with the text's genesis, a decision of an author to reference his previous production, not necessarily with an aesthetic goal in mind, and the fact that the connection is only that because both stories belong to different genres, mobilizing tropes ascribed to them.

Another dubious case regarding its belonging to the Thousand Worlds is the Corpse Handlers stories, which constitute a more contained extended universe on their own. The author explained that several of his early science fiction works were set in the Thousand Worlds, but these were exceptions:

(Though not all of it. "Run to Starlight" and "A Peripheral Affair" are part of a different continuity, the two star ring stories are set in yet another, the corpse stories in a third. "Fast-Friend" stands by itself, as do a number of my other stories. I have no intention of trying to cram these orphans into my future history by retroactive backfill either. That's always a mistake.) (MARTIN, 2006e, p. 144).

In the Corpse Handlers stories, "Meathouse Man" (MARTIN, 2006c) and "Override" (MARTIN, 2018), there are no references to any other story that is undisputedly a part of the Thousand Worlds, but they reference each other. However, in "Nobody Leaves New Pittsburg", a story published in English only once, and therefore, less known than the other two $0^{8}$, the following excerpt can be found: "The good citizens called corpse handlers 'meatminds' - though not to their faces - and saw the whole profession as unclear. Old Earth was like that too. And Newholme and Silversky and Zephyr." (MARTIN, 1976, p 34). Old Earth is a central reference in the Thousand Worlds, and Newholme and Silversky are also frequently mentioned. So how should we take Martin's words as readers in this case, when they contradict strong enough evidence, in

\footnotetext{
8 In Dreamsongs (2006), Martin enumerates these three titles as the corpse-handler stories. No other of his fictional works presents the concept of corpse-handlers, which reinforces the limited range of this fictional universe.
} 
the sense that many other stories are consensually considered as part of this universe on very similar grounds?

Again, the answer is that it depends on the mechanisms we resort to in order to explain these similarities. Martin might have forgotten these mentions in one short story, and then, the argument that the references insert the three stories into a bigger picture weighs more than the author's words to many readers (some might not even be aware of Martin's statements); in this case, the oddity would be explained by means of a generic hypothesis. Also, the belonging of the corpse handlers trilogy to the Thousand Worlds adds a new layer of social inequality to this universe, in which case the justification for the inclusion would be functional. On the other hand, the reader could explain the inconsistency, as most do in regard to "The Lonely Songs of Laren Dorr", as a reference by the author to his previous work. Since the scope of these three stories fit that of other Thousand Worlds works better than the fantasy narratives discussed before, most critics and fans assume they belong to that expanded universe, regardless of the author's own classification.

Yet, sometimes the expanded universe hypothesis will not be enough to explain odd coincidences found in two texts by a same science fiction author. The short story "When It Changed" (2014), by author Joanna Russ, introduced the human colony of Whileaway and built the basis for Russ' greatest success three years later, the novel The Female Man (2010). Narrated by its protagonist, Janet, the plot centers on the arrival of men from Earth in Whileaway, where only women have lived for generations. Aside from one passage where direct speech is marked by commas instead of quotation marks, the short story is not particularly innovative in its aesthetics.. The estrangement typical to science fiction is caused not by a sudden change of deictic expression meanings (STOCKWELL, 2000), as if the reader already knew where and when Janet lived, but is mostly created with contextualized and expositional information. In the first paragraph, the narrator explains that she lives in a place called Whileaway, which is clearly presented as a fictional setting.

The Female Man seems to go similarly during its first paragraphs. The narrator is again Janet, and now we know her name is Janet Evason, in allusion to the first woman in the Judaic/Christian creation myth, Eve, a reference that echoes the pattern for characters' names in "When It Changed". For a few paragraphs, Janet resumes her life, explaining what Whileaway is and how its political and social systems work. However, there are some inconsistencies in this report if we are to compare this protagonist to the Janet we get to know in the short story. Janet's wife, for one, is called Katy in "When It Changed" and Victoria in The Female Man. In both stories, men arrive at Whileaway, but in different circumstances. While Janet and Katy are the ones to find them in "When it Changed", in The Female Man, Janet merely hears some rumors that men were seen for the first time in their land. Also, the novel brings no indication that Whileaway is a colony outside of the Earth; instead, it seems to be a future stage of the planet. In the first story, Janet is a southerner; in the second, she is from the north. 
Several mechanisms of integration could be used by the reader to make sense of said inconsistencies. They could be explained through the genetic mechanism: Joanna Russ made mistakes, she mistook the north for the south, or Victoria for Katy, or the stories are simply not related at all, despite the common names of places and characters. The existential mechanism could offer some explanations too: since it is a science fiction story, and in the Female Man the reader is presented with alternate realities, both characters are parallel versions of Janet in the multiverse. By means of the functional mechanism one could consider that they are not the same Janet, but her and her daughter's names were repeated to create an effect, such as the fragmentation of temporality and the cause/consequence logic. Having in mind that carefully developed expanded universes are the rule, not the exception, among science fiction writers, sticking to the genetic mechanism and assuming that such inconsistencies are nothing but gross mistakes on the part of the author would be a hasty and simplistic conclusion. In applying the other mechanisms of integration, however, the parallel between Russ' works reveals new levels of complexity and experimentalism, a trait that is further reinforced as the novel advances with chapters that break several formal conventions.

Therefore, Sternberg and Yacobi's constructivist approach to narrative integration seems to offer a useful set of tools for the analysis not only of stand-alone literary works, but, as we hope to have demonstrated, to elucidate the intricate relations of fictional works said to be part of expanded universes. In the absence of clear-cut definitions and parameters to determine what expanded universes are and how fictional works are to be ascribed to them, we propose a "cognitivist turn", drawing from Yacobi (1981), which assigns to the reader the power to construct the expanded universe as a hypothesis that integrates textual oddities spotted among fictional works of a given writer. As such, hypothetical expanded universes exist regardless of authorial and/or editorial intention or confirmation, for they are a readers' response to idiosyncrasies that arise from the practice of transtextual reading, a common practice in popular genres such as science fiction.

It should be noted, however, that authors, editors and even authoritative sites of criticism and fan activity do play a role in endorsing or not hypothetical expanded universes. Online forums may be a very recent phenomenon, but they simply update and allow widespread circulation to practices that date back to the origins of sci-fi as a mass genre, such as John W. Campbell's mapping of Heinlein's universe. Curiously enough, though, literary and narrative studies have paid little attention to the inner workings of expanded universes, a fictional trend made even more complex in recent transmedia projects orchestrated by giants of the entertainment industry. Hence, it is our hope that this preliminary study will be complemented, contested, or reviewed so that the applicability of its rationale to a larger number of expanded universes may be verified. 


\section{References}

AGENTS of S.H.I.E.L.D. Season 1. Created by Maurissa Tancharoen, Jed Whedon and Joss Whedon. Directed by Jesse Bochco, Milan Cheylov, Holly Dale, Roxann Dawson, Paul Edwards, Kenneth Fink, Jonathan Frakes, Billy Gierhart, Kevin Hooks, Vincent Misiano, Bobby Roth, David Straiton, John Terlesky and Joss Whedon. Written by Jeffrey Bell, DJ Doyle, Brent Fletcher, Shalisha Francis, Rafe Judkins, Lauren LeFranc, Monica Owusu-Breen, Maurissa Tancharoen, Jed Whedon, Joss Whedon and Paul Zbyszewski. USA: ABC studios, 2013. 22 episodes.

ASIMOV, Isaac. Foundation's Edge. New York: Del Rey, 2012a.

ASIMOV, Isaac. Prelude to Foundation. New York: Spectra, 2012b. ASIMOV, Isaac. Caves of Steel. New York: Spectra, 2011.

CAMPBELL Jr., John W. History to Come. Astounding Science Fiction, New York, vol. 27, n. 3, p. 5-6, May, 1941.

COREY, James S. A. Tiamat's Wrath. New York: Orbit: 2019.

DOCTOR Strange. Directed by Scott Derrickson. Burbank: Marvel Studios, 2016. 1 DVD 115 min.

GOMES, Arthur Maia Baby. PEREIRA, Gabriela Pirotti. Em Castelos Vazios: medievalismo e romantismo em As Canções Solitárias de Laren Dorr e Nas Terras Perdidas, de George R. R. Martin. Entrelaces, Fortaleza, v. 8, n. 20, p. 279-296, jun. 2020.

KENNEDY, Gerald. Modern American Short Story Sequences: Composite Fictions and Fictive Communities. New York: Cambridge University Press, 1995.

LYDEN, John. Whose Film Is It, Anyway? Canonicity and Authority in Star Wars Fandom. Journal of the American Academy of Religion, Volume 80, Issue 3, September 2012, Pages 775-786. Available at: https://academic.oup.com/jaar/article/80/3/775/710872. Accessed: April, $24^{\text {th }}, 2021$.

LE GUIN, Ursula K. The Left Hand of Darkness. New York: Penguin Random House, 2018.

LE GUIN, Ursula K. Another Story or A Fisherman of the Inland Sea. In: The Lost and the Found. New York: Saga Press, 2016.

LE GUIN, Ursula K. The Word for World is Forest. London: Gollancz, 2015.

LE GUIN, Ursula K. The Birthday of the World. Winnipeg: Gateway, 2010.

LE GUIN, Ursula K. The Dispossessed. New York: Harper Voyager, 2011.

MARTIN, George R. R. A Feast for Crows. New York: Bantam, 2012.

MARTIN, George R. R. And Seven Times Never Kill Man. In: MARTIN, George R. R. Dreamsongs, Vol I. London: Gollancz, 2006a.

MARTIN, George R. R. Dreamsongs, Vol I. London: Gollancz, 2006b. MARTIN, George R. R. Dying of the Light. London: Gollancz, 2015. MARTIN, George R. R. In The House of the Worm. Electricstory.com, 2005. 
MARTIN, George R. R. Last Year (Writing, Editing, Producing). Not a Blog, Santa Fe, Jan. 1st, 2016. Available at:

https://web.archive.org/web/20160610191802/https://grrm.livejournal.co m/464984.html?thre ad=23461208. Accessed: April, 24th, 2021.

MARTIN, George R. R. Meathouse Man. In: MARTIN, George R. R. Dreamsongs, Vol I. London: Gollancz, 2006c.

MARTIN, George R. R. Nobody Leaves New Pittsburg. Amazing Science Fiction, New York, vol 50, n. 2, p. 26-35, September, 1976.

MARTIN, George R. R. Override. In: MARTIN, George R. R. Nightflyers \& Other Stories. New York: Tor Books, 2018.

MARTIN, George R. R. The Glass Flower. In: MARTIN, George R. R. Dreamsongs, Vol I. London: Gollancz, 2006d.

MARTIN, George R. R. The Light of Distant Stars. In: MARTIN, George R. R. Dreamsongs, Vol I. London: Gollancz, 2006e.

MARTIN, George R. R. The Lonely Songs of Larren Dorr. In: MARTIN, George R. R. Dreamsongs, Vol I. London: Gollancz, 2006f.

MARTIN, George R. R. This Tower of Ashes. In: MARTIN, George R. R. Dreamsongs, Vol I. London: Gollancz, 2006g.

MARTIN, George R. R. Tuf Voyaging. London: Gollancz, 2014.

MARVEL'S Cloak and Dagger. Season 1. Created by Joe Pokaski. Directed by Paul Edwards, Peter Hoar, Alex Garcia Lopez, Ami Canaan Mann, Jennifer Phang, Gina PrinceBythewood, Jeff Woolnough, Wayne Yip and Ry Russo-Young. Written by Ariella Blejer, Christine Boylan, Peter Calloway, J. Holtham, Dawn Kamoche, Jenny Klein, Niceole R. Levy and Joe Pokaski. USA: ABC studios, 2018. 10 episodes.

MARVEL'S Runaways. Season 1. Created by Stephanie Savage and Josh Schwartz. Directed by Roxann Dawson, Jeffrey W. Byrd, Peter Hoar, Marc Jobst, Nina LopezCorrado, Brett Morgen, Ramsey Nickell, Patrick Norris, Millicent Shelton and Jeremy Webb. Written by Rodney Barnes, Tamara Becher-Wilkinson, Jiehae Park, Quinton Peeples, Stephanie Savage, Josh Schwartz, Kalinda Vazquez and Michael Vukadinovich. USA: ABC Signature Studios/Marvel Television, 2017.

MENDLESOHN, Farah. Introduction: Reading Science Fiction. In: JAMES, Edward (Ed.); MENDELSOHN, Farah. (Ed.) The Cambridge Companion to Science Fiction. Cambridge: Cambridge University Press, 2003.

MKKAAAYYYY. (Spoilers Everything) The Pale Child Bakkalon. Reddit. Topic on online forum. 2017. Available at:

https://www.reddit.com/r/asoiaf/comments/4wzr20/spoilers_everything_th e_pale_child_bakk alon. Accessed: April 24th, 2021.

POPPA Chase. Is Planetos part of the Thousand Worlds? A Forum of Ice and Fire. Topic on online forum. 2015. Available at: https://asoiaf.westeros.org/index.php?/topic/132424-is-planetos-part-ofthe-thousand-worlds. Accessed: April 24th, 2021. 
REID, Robin Anne. Fan Studies. In: BOULD, Mark; BUTLER, Andrew; ROBERTS, Adam; VINT, Sherryl. The Routledge Companion to Science Fiction. Oxon: Routledge, 2009. P. 382- 392.

RUSS, Joanna. The Female Man. London: Orion, 2010.

RUSS, Joanna. When it Changed. In: ELLISON, Harlan (ed). Again, Dangerous Visions. New York: Open Road Media Sci-Fi \& Fantasy, 2014.

RYAN, Marie-Laure. The Modal Structure of Narrative Universes. Poetics Today, 1985, Vol. 6, No. 4 (1985), pp. 717-755. Durham: Duke University Press, 1985.

RYAN, Marie-Laure. Transmedia Storytelling: Industry Buzzword or New Narrative Experience? Storyworlds, Lincoln, vol. 7, n. 2, p. 1-19, Winter, 2015.

SAINT-GELAIS, Rirchard. Fictions Transfuges: La Transfictionnalité et ses enjeux. Paris: Édition du Seuil, 2011.

SHELLEY, Mary. Frankenstein, or the Modern Prometheus. London: Flame Tree Collections, 2011.

STERNBERG, Meir. Expositional Modes and Temporal Ordering in Fiction. Baltimore: John Hopkings University Press, 1978.

STERNBERG, Meir; YACOBI, Tamar. (Un)Reliability in Narrative Discourse: a Comprehensive Overview. In: Poetics Today. Vol. 36, N. 4. Duke University Press: December 2015. pp. 327-498.

STOCKWELL, Peter. The Poetics of Science Fiction. London: Longman, 2000.

THE Avengers. Directed by Joss Whedon. Burbank: Marvel Studios, 2012. 1 DVD 143 min.

THELETHALCARROT. Does A Song of Ice and Fire take place in The Thousand Worlds? Stack Exchange. Topic on Online Forum. 2018. Available at: https://scifi.stackexchange.com/questions/180440/does-a-song-of-ice-andfire-take-place-in-the-thousand-worlds. Accessed: April 24th, 2021.

WANDAVISION. Season 1. Created by Jac Schaffer. Directed by: Matt Shakman. Written by: Peter Cameron, Mackenzie Dohr, Laura Donney, Gretchen Enders, Bobak Esfarjani, Chyck Hayward, Megan McDonnel, Jac Schaeffer and Cameron Squires. Burbank: Marvel Studios, 2021.

WATSON, Ian. Le Guin's Lathe of Heaven and the Role of Dick: The False Reality as Mediator. Science Fiction Studies, Greencastle, vol. 2, n. 5, p. 67-75, March, 1975.

YACOBI, Tamar. Fictional Reliability as a Communicative Problem. In: Poetics Today. v. 2, n. 2. Duke University Press: Winter 1981, p. 113-126.

Artigo enviado em: 28/04/2021. Aprovado em: 21/06/2021. 